Original Research Paper

\title{
Kinematic and Dynamic Analysis of a Classic, Three-Axis Manual Gearbox, Without a Direct Socket
}

\author{
Relly Victoria Virgil Petrescu and Florian Ion Tiberiu Petrescu \\ ARoTMM-IFToMM, Bucharest Polytechnic University, Bucharest, (CE), Romania
}

\author{
Article history \\ Received: 05-04-2020 \\ Revised: 28-04-2020 \\ Accepted: 23-05-2020 \\ Corresponding Author: \\ Relly Victoria Virgil Petrescu \\ ARoTMM-IFToMM, Bucharest \\ Polytechnic University, \\ Bucharest, (CE), Romania \\ Email: rvvpetrescu@gmail.com
}

\begin{abstract}
Fixed axis mechanical transmissions today have the largest spread on the entire planet, being practically used in almost all areas. From the gearboxes of the vehicles to the stationary reducers, used in the electrical, electronic and electro technical equipment, in the heavy industry but also in the light industry, in energy and in transport, practically the transmissions with fixed axes meet today everywhere, being part of our daily life. For this reason, we want to present the kinematic and dynamic analysis at a classic, manual, three-axis gearbox, with six speeds, without a direct socket. With the help of the presented method, one can analyze the dynamics of such a gearbox in order to design it optimally, so as to achieve the highest yields in operation, especially in the most used speeds, so that the transmission losses are limited to up.
\end{abstract}

Keywords: Automation, Mechatronic Systems, Mechanical Transmissions, Gearboxes, Gearing, Manual Gearbox, Three-axis Gearbox, Six Speeds Gearbox, Dynamics

\section{Introduction}

The beginning of the use of bar and gear mechanisms must be sought in ancient Egypt at least a thousand years before Christ. Here, for the first time, the "spiked" wheel transmissions were used for irrigation of crops as well as the snail gears for cotton processing (Fig. 1).

Such gears have been built and used since ancient times, initially for lifting heavy ship anchors as well as for pretensioning catapults used on battlefields. They were then introduced to machines with wind and water (as reducers or multipliers to pumps, windmills, or water).

230 years BC, in the city of Alexandria in Egypt, the multi-lever wheel and rack gear were used.

The transmission of the gear by means of gears with gears has seen substantial progress since 1364 AD when the Italian craftsman Giovani da Dondi made an astronomical clock, whose composition included interior gears and elliptical gears.

The first gear adjustable gears were used in 1769 by Cugnot to equip the first vehicle powered by a steam engine (Fig. 2).

The first engineer (scientist), who actually designs such transmissions, is considered to be the Italian master Leonardo da Vinci (15th century) (Fig. 3).

The Benz engine (Fig. 4) had gears with gears but also with chain gears (patented after 1882). On the Fig. 5 , you can see the sketch of the first gearbox with gears (gears) and chain gears made in 1870 by the British Starley and Hillman.
After 1912, in Cleveland (USA), specialized manufacturing of wheels, gears and gears (cylindrical, screw, conical, with straight, inclined or curved teeth) begins to be produced. Gearboxes with fixed axles have the widest spread on all types of vehicles (Fig. 6).

Gearboxes are independent gearboxes with permanent gear, mounted on shafts and enclosed in a watertight housing. They serve:

- Speed reduction

- Increase of the transmitted moment

- Modification of the direction of rotation or the plane of movement

- Sum the power flow from several motors to a work machine

- Distributes the power flow from one motor to several work machines.

In the case of speed reducers, the gear wheels are fixedly fixed to the shafts, permanently engage and realize a totally fixed transmission ratio, defined as the ratio between the speed at the input and the speed at the output of the gearbox, as opposed to the gearboxes at which some wheels are movable. On shafts (balancing wheels), intermittently gears and performs a total gear ratio. They are also different from the gear speed variants (used less frequently), where the total transmission ratio can be continuously varied. 


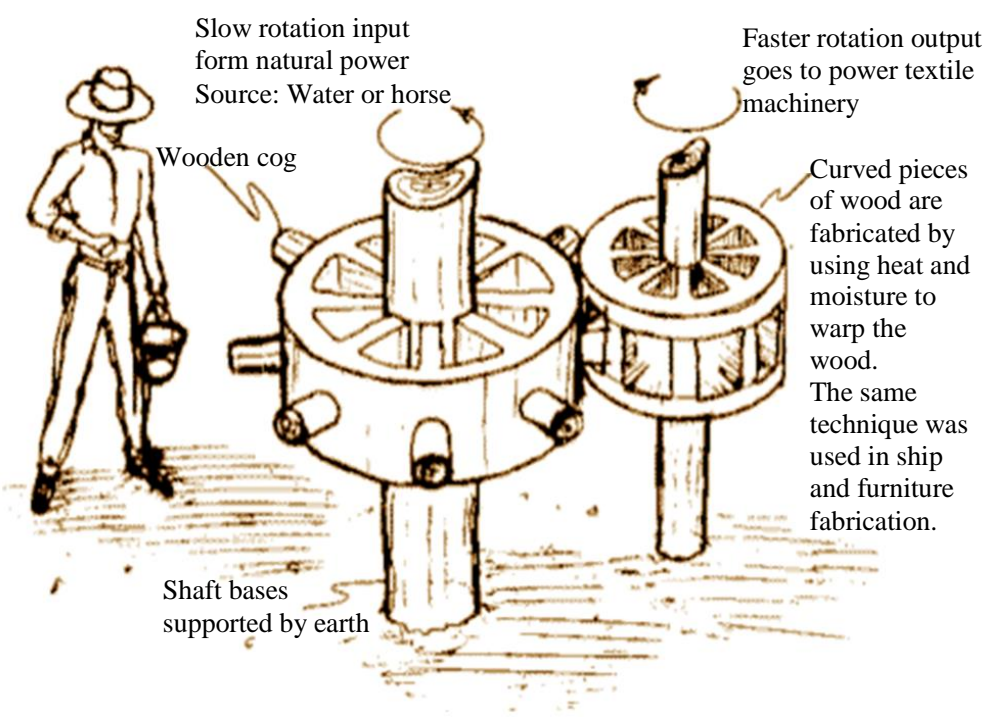

Fig. 1: Ancient Egypt at least a thousand years before Christ. Here, for the first time, the "spiked" wheel transmissions were used for irrigation of crops

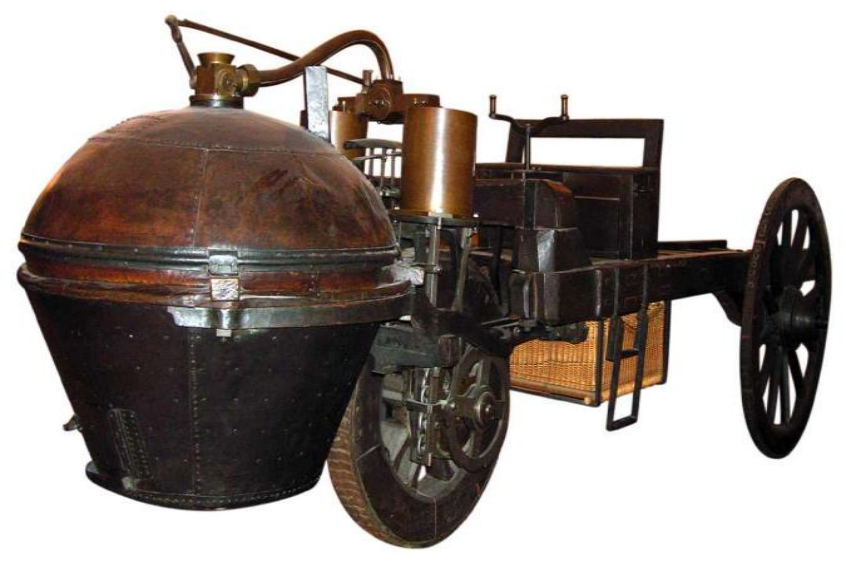

Fig. 2: The first adjustable gearboxes were used in 1769 by Cugnot to equip the first vehicle powered by a steam engine

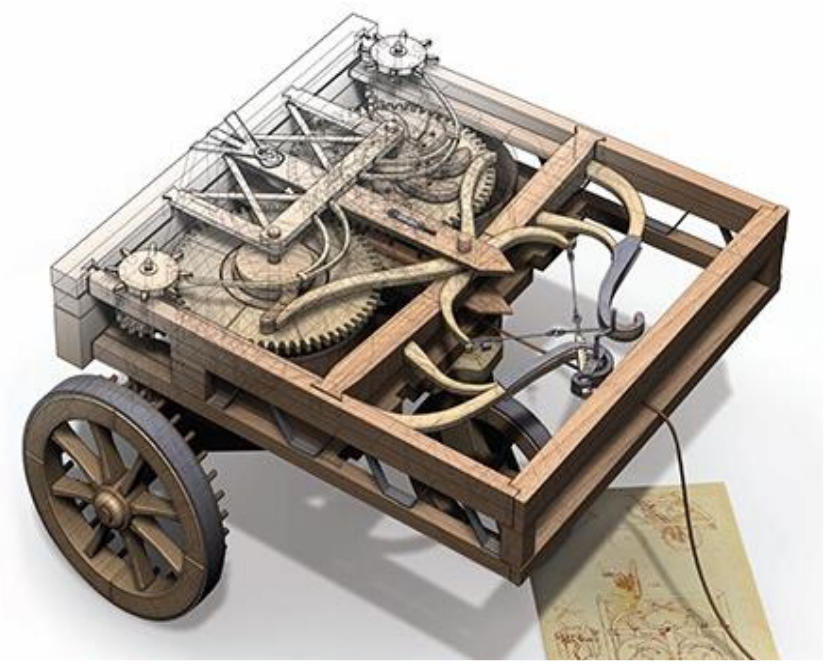

Fig. 3: Car of the Italian craftsman Leonardo da Vinci (15th century) 


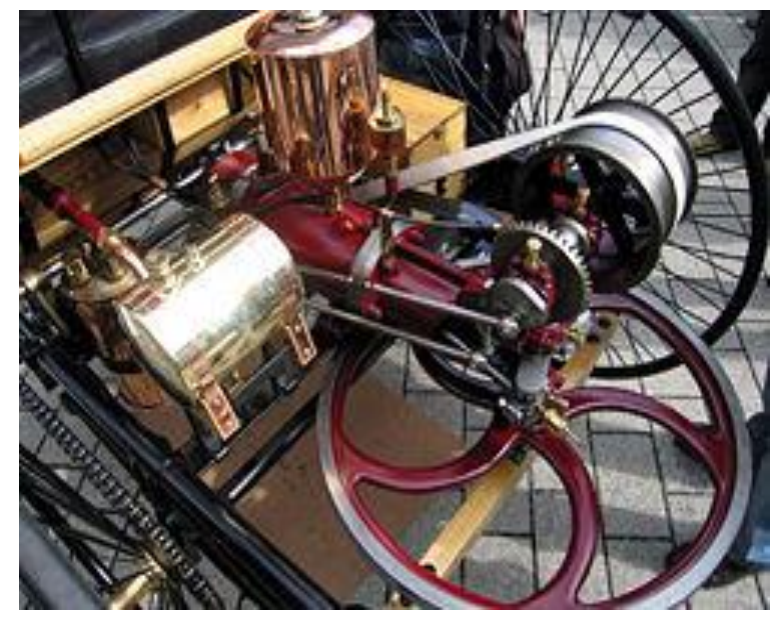

Fig. 4: The Benz engine had gears with gears

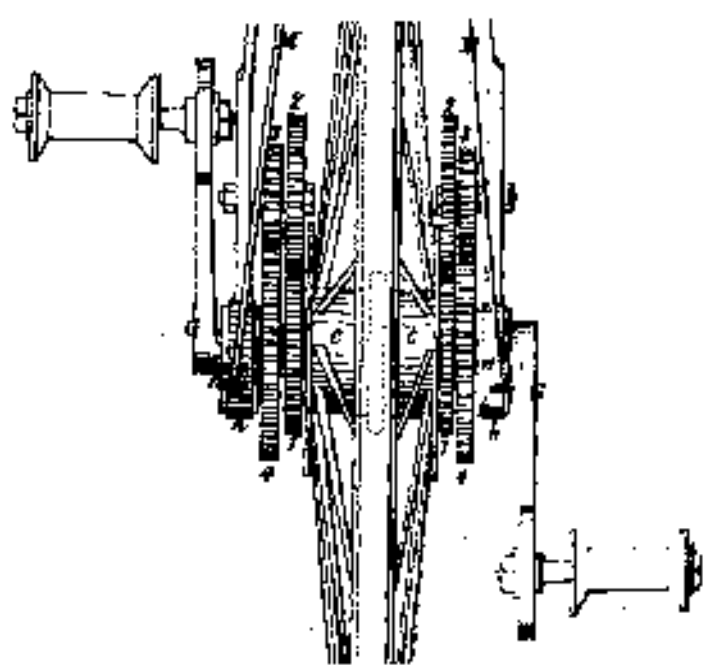

Fig. 5: Sketch of a first patent for cogwheels and cogwheels made in 1870 by the British Starley and Hillman

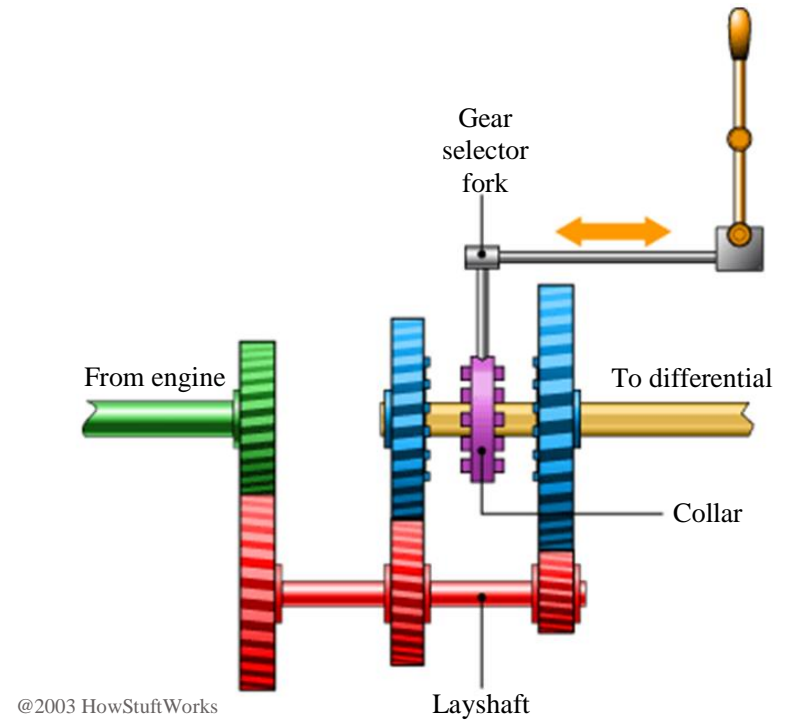

Fig. 6: Gearboxes with fixed axles have the widest spread on all types of vehicles 
Gear speed reducers are used in all areas of machine construction (Brewer, 1991).

There is a great variety of speed reducers. They are classified according to the following criteria:

1. After the transmission report

a. Reducers with a speed reduction step

b. Gearboxes with two or more speed reducers

2. According to the relative position of the input shaft (motor) and the output shaft

a. Coaxial reducers (with return), in which the input shaft is coaxial with the output one

b. Parallel reducers, in which the input and output shafts are parallel

3. According to the position of the shafts
a. Reducers with horizontal axes
b. Reducers with vertical axes
c. Reducers with inclined axes

4. By gear type
a. Cylindrical reducers
b. Tapered reducers
c. Hypoid reducers
d. Gear reducers
e. Combined reducers (cylinder-conical, cylinder- snails, etc.,)
f. Planetary reducers

5. By type of axes
a. Fixed axis reducers
b. Reducers with movable axles

If the gear unit together with the motor constitutes a single aggregate (the motor is driven directly to the input shaft by a flange) then the unit is called a Gearmotor.

In many constructive solutions, gear reducers with gear wheels are used in kinematic schemes along with other types of transmissions: By belts, chains, friction, screw-nut, speed variator, gearboxes, etc.

The advantages of using reducers in the kinematic diagrams of machines and mechanisms are:

- Constant transmission report

- $\quad$ Ensures a wide range of powers

- Relatively small gauge

- High efficiency (with the exception of gear reducers)

- Simple and cheap maintenance

Disadvantages include:

- High-cost price

- The need for precision machining and assembly

- Their operation is accompanied by noise and vibration
The main parameters of a gearbox are:

- Nominal power

- The transmission report mad

- Input shaft speed

- Distance between axes (standardized)

Due to the multiple uses in the machine-building industry and various devices, the gear speed parameters are standardized.

The choice of gearbox type in a kinematic scheme is made according to:

- The required transmission report

- The nominal power required

- $\quad$ Average load required

- The average working speed required

- Available size

- The relative position of the axes of the motor and of the working organ (machine)

- The overall efficiency of the kinematic scheme

Depending on these requirements, the following types of gear units can be used: Cylindrical, conical, conical-cylindrical, screw, cylinder-screw, planetary.

Gearboxes with cylindrical gears. These are the most used types of gear reducers because:

- They are produced in a wide range of powers: From very small installed powers (of the order of the Watts) to $900000 \mathrm{~W}(900 \mathrm{~kW})$

- $\quad$ Total transmission ratios, iT $\max =200(\mathrm{iT} \max =$ 6.3 , for one-stage reducers; iT $=60$, for 2 -speed reducers, $\mathrm{iT}=200$, for 3 -speed reducers)

- High peripheral speeds, Vmax $=200 \mathrm{~m} / \mathrm{s}$

- The possibility of typing and standardized or standardized execution

They are constructed in versions with 1,2 and 3 reduction stages, with straight or inclined teeth. The notations in the figure are:

- Entry into the gearbox, with the letter I

- Exit from the gearbox, with the letter E

- The Fig. 1 to 6 , represent the wheels that make up the gears of the reduction gears

From the point of view of the inclination of the gear, when choosing the type of gearbox with cylindrical gears, the following recommendations are taken into account:

- Gearboxes with straight cylindrical gears, for small and medium installed powers, small and medium peripheral speeds and to the ball wheels from the gearboxes 
- Gear units with inclined cylindrical gear wheels, for small and medium installed powers, high peripheral speeds, silent gears

- Gearboxes with cylindrical V-toothed gears, for high installed powers and low peripheral speeds (Fig. 7)
The classic gearboxes, manual, the most widespread and most used, are mainly of three types: With two axes (Fig. 8), with three axes with welding the input and output shafts in the direct socket (Fig. 9), with three axles without welding shafts (Fig. 10).

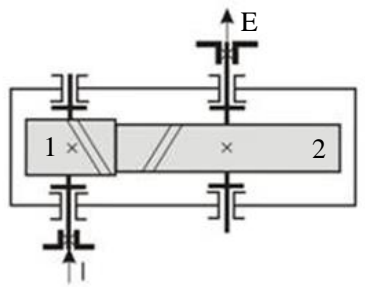

(a)

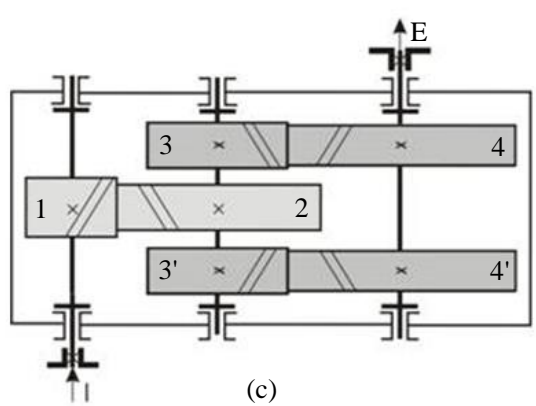

(c)

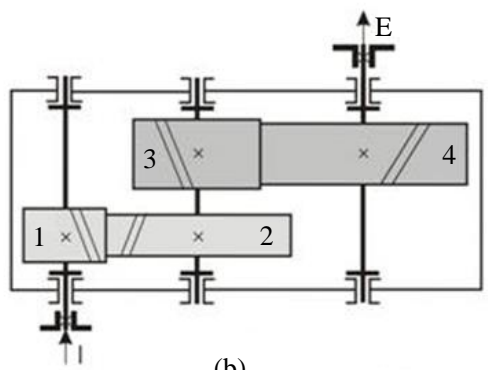

(b)

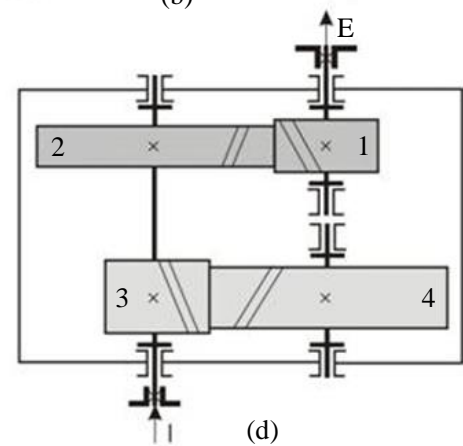

(d)

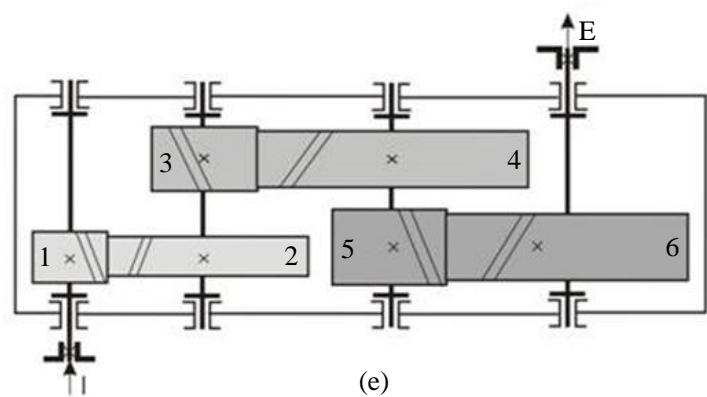

Fig. 7: Kinematic diagrams for cylindrical gearboxes

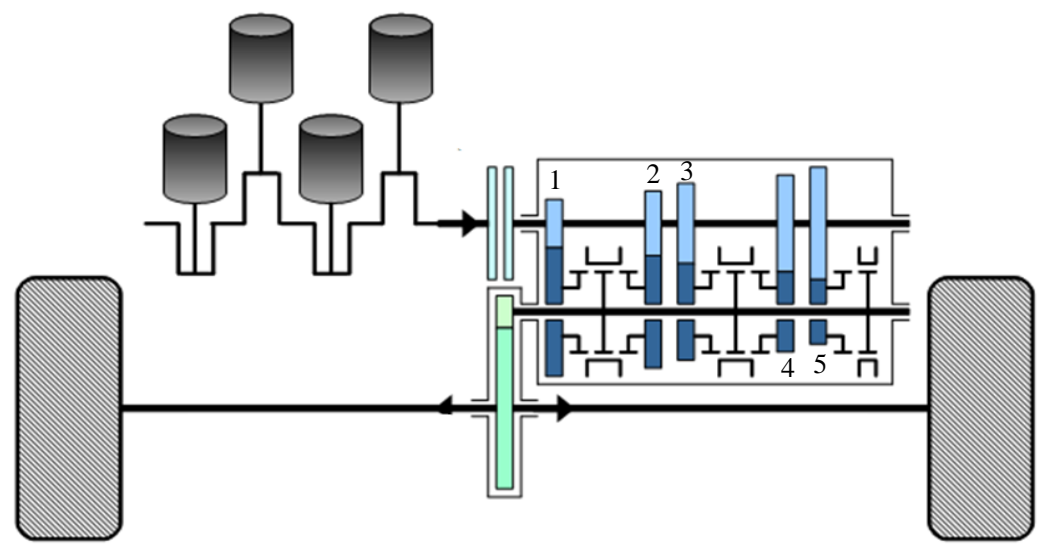

Fig. 8: The classic gearboxes, manual, with two axes 


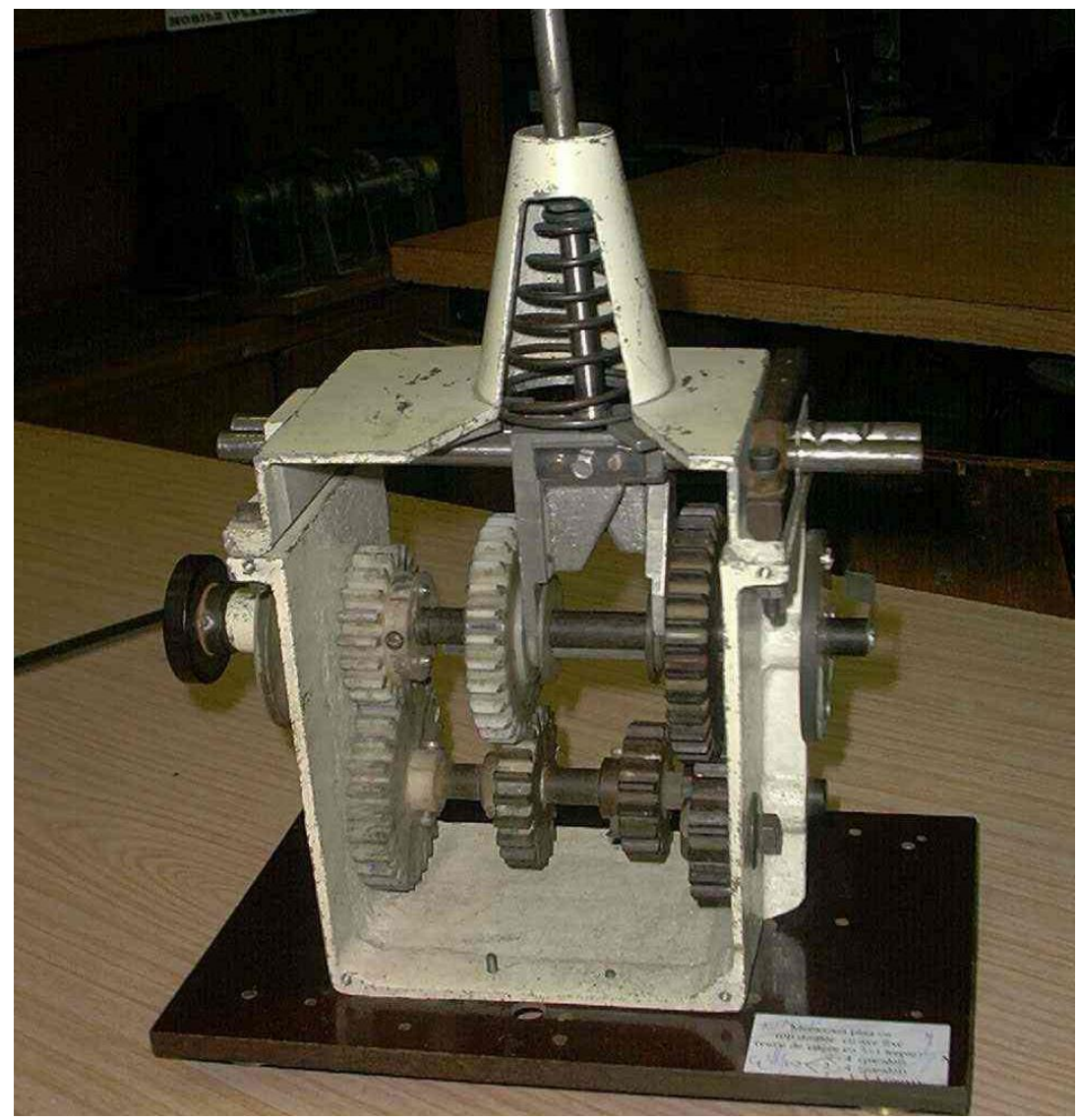

Fig. 9: The classic gearboxes, manual, with three axes with welding the input and output shafts in the direct socket

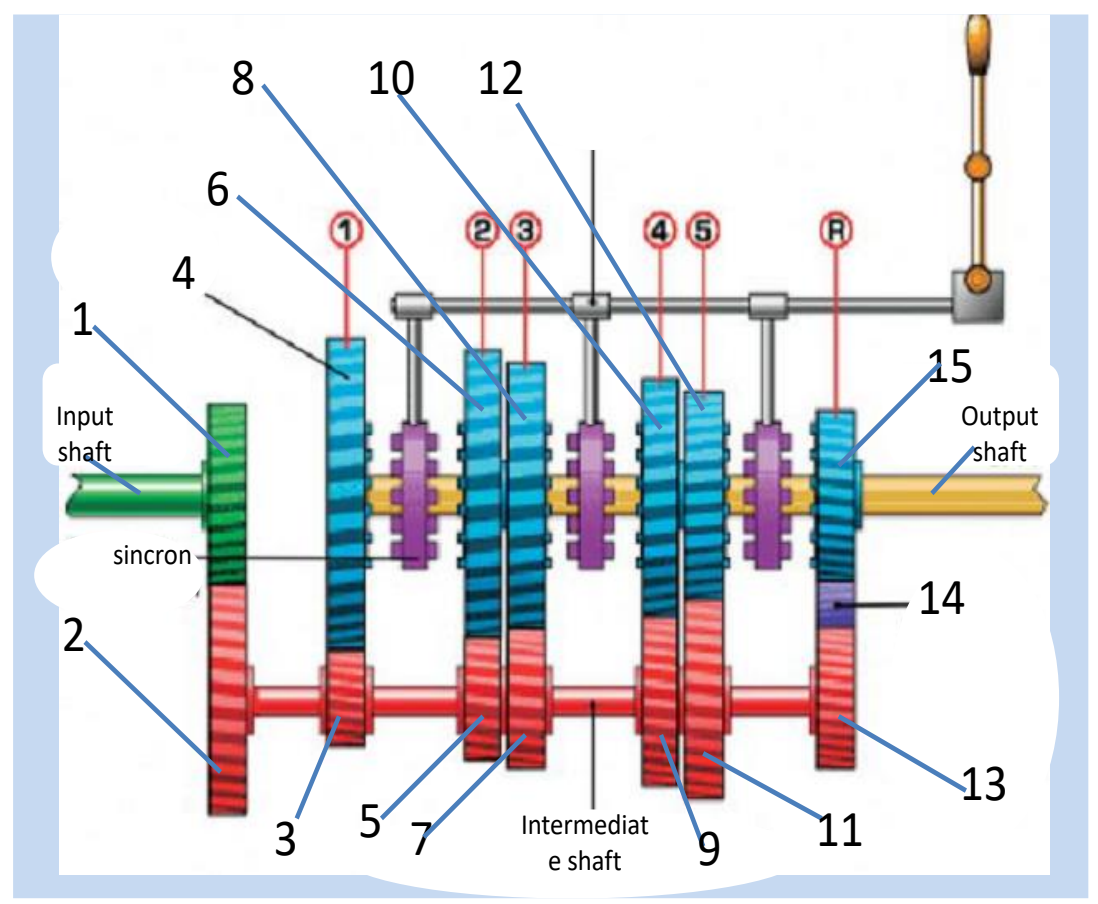

Fig. 10: Classic, manual, three-axis gearboxes without welding the input and output shafts directly 
The great advantage of such a system is that the input and output gears are practically welded, i.e., the input shaft is attached to the output shaft in the main direct socket, the transmission ratio becomes 1 and the power lost in this step is very low. Intensely used on the long road being zero, so $100 \%$ practical efficiency.

Other gears are not very convenient, however, with lower efficiency and when walking in the city, where the lower gears are used, the gearbox in Fig. 9 with welding shafts, it is no longer advantageous (Antonescu and Petrescu, 1985; 1989; Antonescu et al., 1985a; 1985b; 1986; 1987; 1988; 1994; 1997; 2000a; 2000b; 2001; Aversa et al., 2017a; 2017b; 2017c; 2017d; 2017e; 2016a; 2016b; 2016c; 2016d; Cao et al., 2013; Dong et al., 2013; Franklin, 1930; He et al., 2013; Lee, 2013; Lin et al., 2013; Liu et al., 2013; Padula and Perdereau, 2013; Perumaal and Jawahar, 2013; Petrescu, 2011; 2012; 2019; Petrescu and Petrescu, 1995a; 1995b; 1997a; 1997b; 1997c; 2000a; 2000b; 2002a; 2002b; 2003; 2005a; 2005b; 2005c; 2005d; 2005e; 2011ac; 2012a; 2012b; 2013a-e; 2014a-h; 2016a; 2016b; 2016c; Petrescu et al., 2007; 2009; 2016; 2017a; 2017b; 2017c; 2017d; 2017e; 2017f; 2017g; 2017h; 2017i; 2017j; 2017k; 2017l; 2017m; 2017n; 2017o; $2017 \mathrm{p} ; 2017 \mathrm{q} ; 2017 \mathrm{r} ; 2017 \mathrm{~s} ; 2017 \mathrm{t} ; 2017 \mathrm{u} ; 2017 \mathrm{v}$; 2017w; 2017x; 2018a; 2018b; 2018c; 2018d; 2018e; 2018f; 2018g; Petrescu and Petrescu, 2019a-c; Petrescu and Calautit, 2016a-b; Svensson et al., 2004).

\section{Materials and Methods}

A more convenient solution is the one presented in Fig. 10, with three axes without welding shafts, a solution that will be carried out in this work both the kinematic analysis of the gearbox and the dynamic analysis (determination of yields) for the main city steps.

One has 15 gear wheels from 1 to 15 , whose tooth numbers are given in Table 1 .

The input shaft 1 is a sprocket with gear 1 which is therefore fixed to the shaft and rotates permanently with it, the intermediate or auxiliary shaft 2 has on it 7 gear wheels, 3, 5, 7, 9, 11, 13, which are fixed on the shaft and rotate permanently with the shaft 2 helpers permanently transmitting the movement and to the wheels on the output shaft 3 which rotate all the time and have permanent power but transmit it to the output shaft only when they are coupled and the output shaft 3 has freely mounted on it all its gear wheels $4,6,8,10,12,15$, which will be coupled with the output shaft only one at a time depending on the trap chosen by means of synchronous wheels. There are also ballast mechanisms that prevent the coupling of two steps simultaneously.
Table 1: Tooth numbers

\begin{tabular}{lllll}
\hline Z1 & Z2 & Z3 & Z4 & Z5 \\
\hline 40 & 48 & 16 & 50 & 18 \\
Z6 & Z7 & Z8 & Z9 & Z10 \\
20 & 20 & 16 & 24 & 16 \\
Z11 & Z12 & Z13 & Z14 & Z15 \\
36 & 18 & 20 & 16 & 50 \\
\hline
\end{tabular}

Dynamic analysis of the classic gearbox mechanism, manually, with three axes without solidification steps.

The gearbox efficiency analyzed in the three frequently used steps, 3, 4 and 5, is further determined.

The calculation relationships used in succession are the two below, (I) and (II), only for external gears:

$$
\begin{aligned}
& \varepsilon^{a . e .}=\frac{1+\operatorname{tg}^{2} \beta}{2 \cdot \pi} \cdot\left\{\sqrt{\left[\left(z_{1}+2 \cdot \cos \beta\right) \cdot \operatorname{tg} \alpha_{0}\right]^{2}+4 \cdot \cos ^{3} \beta \cdot\left(z_{1}+\cos \beta\right)}\right. \\
& \left.+\sqrt{\left[\left(z_{2}+2 \cdot \cos \beta\right) \cdot \operatorname{tg} \alpha_{0}\right]^{2}+4 \cdot \cos ^{3} \beta \cdot\left(z_{2}+\cos \beta\right)}-\left(z_{1}+z_{2}\right) \cdot \operatorname{tg} \alpha_{0}\right\} \\
& \eta_{m}=\frac{z_{1}^{2} \cdot \cos ^{2} \beta}{z_{1}^{2}\left(\operatorname{tg}^{2} \alpha_{0}+\cos ^{2} \beta\right)+\frac{2}{3} \pi^{2} \cos ^{4} \beta(\varepsilon-1)(2 \varepsilon-1) \pm 2 \pi \operatorname{tg} \alpha_{0} z_{1} \cos ^{2} \beta(\varepsilon-1)}
\end{aligned}
$$

\section{Results and Discussion}

For the reverse gear, there is an additional gear wheel 14 which reverses the direction of rotation of the output shaft but only in the reverse gear 6 .

Kinematic analysis of the classic gearbox mechanism, manually, with three axes without solidification steps.

The transmission reports made by this classic (manual) gearbox are determined (Table 2):

1) $\eta_{0}$ is determined for gear 1.2 directly with relations I and II:

$$
\begin{gathered}
\eta_{0} \\
0,853922
\end{gathered}
$$

2) $\eta_{78}$ is determined for gear 7.8 with relations I and II, where 1 is replaced by 7 and 2 is replaced by 8 . The yield in step 3 is then obtained through the product between the yield 0 and that of gear $7.8 ; \eta_{3}=\eta_{0} \cdot \eta_{78}$ :

$$
\begin{gathered}
\eta_{78} \\
0,833237 \\
\eta_{3} \\
0,711519
\end{gathered}
$$

3) $\eta_{9,10}$ is determined for the gear 9.10 with relations I and II, where 1 is replaced by 9 and 2 is replaced by 10. The yield in step 4 is then obtained by the product between the yield 0 and that of the gear 9.10; $\eta_{4}=\eta_{0} \cdot \eta_{9,10}$ : 


$$
\begin{gathered}
\eta_{9,10} \\
0,842036 \\
\eta_{4} \\
0,719033
\end{gathered}
$$

4) $\eta_{11,12}$ is determined for the gear 11.12 with relations I and II, where 1 is replaced by 11 and 2 is replaced by 12 . The yield in step 5 is then obtained by the product between the yield 0 and that of the gear $11.12 ; \eta_{5}=\eta_{0} \cdot \eta_{11,12}$ :

$$
\begin{gathered}
\eta_{11,12} \\
0,856361 \\
\eta_{5} \\
0,731265
\end{gathered}
$$

The angles $\alpha_{0}, \beta$ are constant for all the gears of this gearbox as follows: $\alpha_{0}=18.6, \beta=16$.

The efficiency results in the main gears, which are used more often by the driver of the vehicle, are generally high and could be optimized so that they are even higher with the optimum design of the gearbox, with gears having a larger number of teeth and possibly with decreasing the pressure angle normal on the division circle to an optimum value.

Next, another optimized constructive variant will be presented (Table 3 and 4).

1) $\eta_{0}$ is determined for gear 1.2 directly with relations I and II:

$$
\begin{gathered}
\eta_{0} \\
0,82513
\end{gathered}
$$

2) $\quad \eta_{78}$ is determined for gear 7.8 with relations I and II, where 1 is replaced by 7 and 2 is replaced by 8 . The yield in step 3 is then obtained through the product between the yield 0 and that of gear 7.8; $\eta_{3}=\eta_{0} \cdot \eta_{78}$ :

$$
\begin{gathered}
\eta_{78} \\
0,80379 \\
\eta_{3} \\
0,66323
\end{gathered}
$$

3) $\eta_{9,10}$ is determined for the gear 9.10 with relations I and II, where 1 is replaced by 9 and 2 is replaced by 10. The yield in step 4 is then obtained by the product between the yield 0 and that of the gear 9.10; $\eta_{4}=\eta_{0} \cdot \eta_{9,10}$ :

\section{0,66962}

4) $\eta_{11,12}$ is determined for the gear 11.12 with relations I and II, where 1 is replaced by 11 and 2 is replaced by 12 . The yield in step 5 is then obtained by the product between the yield 0 and that of the gear $11.12 ; \eta_{5}=\eta_{0} \cdot \eta_{11,12}$ :

$$
\begin{gathered}
\eta_{11,12} \\
0,82433
\end{gathered}
$$

0,68018

The angles $\alpha_{0}, \beta$ are constant for all the gears of this gearbox, as follows: $\alpha_{0}=19.9, \beta=29$ :

As can be seen from the new values, the transmission ratios in the five forward gears of the gearbox are much optimized, even if their output yield is slightly lower. This efficiency can be increased significantly, especially for the most used steps by drivers, $3,4,5$, through a new constructive scheme in which the number of teeth of the wheels will be much higher and eventually the pressure angle of the wheels will be reduced (alpha 0 ).

Table 2: The transmission reports made by this classic (manual) gearbox

\begin{tabular}{lllll}
\hline $\mathrm{i}_{0}=\mathrm{i}_{12}$ & $\mathrm{i}_{34}$ & $\mathrm{i}_{56}$ & $\mathrm{i}_{78}$ & $\mathrm{i}_{9,10}$ \\
\hline$=-\mathrm{z} 2 / \mathrm{z} 1$ & $=-\mathrm{z} 4 / \mathrm{z} 3$ & $=-\mathrm{z6} / \mathrm{z} 5$ & $=-\mathrm{z} 8 / \mathrm{z} 7$ & $=-\mathrm{z} 10 / \mathrm{z} 9$ \\
$-1,2$ & $-3,125$ & $-1,11111$ & $-0,8$ & $-0,66667$ \\
$\mathrm{i}_{11,12}$ & $\mathrm{i}_{13,14}$ & $\mathrm{i}_{14,15}$ & $\mathrm{i}_{1}$ & $\mathrm{i}_{2}$ \\
$=-\mathrm{z} 12 / \mathrm{z} 11$ & $=-\mathrm{z} 14 / \mathrm{z} 13$ & $=-\mathrm{z} 15 / \mathrm{z} 14$ & $=\mathrm{i}_{0} \mathrm{i}_{34}$ & $=\mathrm{i}_{0} \mathrm{i}_{56}$ \\
$-0,5$ & $-0,8$ & $-3,125$ & 3,75 & 1,333333 \\
$\mathrm{i}_{3}$ & $\mathrm{i}_{4}$ & $\mathrm{i}_{5}$ & $\mathrm{i}_{6}=\mathrm{i}_{\mathrm{MR}}$ & \\
$=\mathrm{i}_{0} \mathrm{i}_{78}$ & $=\mathrm{i}_{0} \mathrm{i}_{9,10}$ & $=\mathrm{i}_{0} \mathrm{i}_{11,12}$ & $=\mathrm{i}_{0} \mathrm{i}_{13,14} \mathrm{i}_{14,15}$ \\
0,96 & 0,8 & 0,6 & -3 & \\
\hline
\end{tabular}

Table 3: Another optimized constructive variant

\begin{tabular}{lllll}
\hline Z1 & Z2 & Z3 & Z4 & Z5 \\
\hline 40 & 48 & 16 & 50 & 18 \\
Z6 & Z7 & Z8 & Z9 & Z10 \\
30 & 20 & 24 & 24 & 24 \\
Z11 & Z12 & Z13 & Z14 & Z15 \\
36 & 27 & 20 & 16 & 50 \\
\hline
\end{tabular}

Table 4: Another optimized constructive variant

\begin{tabular}{lllll}
\hline $\mathrm{i}_{0}=\mathrm{i}_{12}$ & $\mathrm{i}_{34}$ & $\mathrm{i}_{56}$ & $\mathrm{i}_{78}$ & $\mathrm{i}_{9,10}$ \\
\hline$=-\mathrm{z} 2 / \mathrm{z} 1$ & $=-\mathrm{z} 4 / \mathrm{z3}$ & $=-\mathrm{z6} / \mathrm{z} 5$ & $=-\mathrm{z} 8 / \mathrm{z} 7$ & $=-\mathrm{z} 10 / \mathrm{z} 9$ \\
$-1,2$ & $-3,125$ & $-1,667$ & $-1,2$ & -1 \\
$\mathrm{i}_{11,12}$ & $\mathrm{i}_{13,14}$ & $\mathrm{i}_{14,15}$ & $\mathrm{i}_{1}$ & $\mathrm{i}_{2}$ \\
$=-\mathrm{z} 12 / \mathrm{z} 11$ & $=-\mathrm{z} 14 / \mathrm{z} 13$ & $=-\mathrm{z} 15 / \mathrm{z} 14$ & $=\mathrm{i}_{0} \mathrm{i}_{34}$ & $=\mathrm{i}_{0} \mathrm{i}_{56}$ \\
$-0,75$ & $-0,8$ & $-3,125$ & 3,75 & 2 \\
$\mathrm{i}_{3}$ & $\mathrm{i}_{4}$ & $\mathrm{i}_{5}$ & $\mathrm{i}_{6}=\mathrm{i}_{\mathrm{MR}}$ & \\
$=\mathrm{i}_{0} \mathrm{i}_{78}$ & $=\mathrm{i}_{0} \mathrm{i}_{9,10}$ & $=\mathrm{i}_{0} \mathrm{i}_{11,12}$ & $=\mathrm{i}_{0} \mathrm{i}_{13,14} \mathrm{i}_{14,15}$ & \\
1,44 & 1,2 & 0,9 & -3 & \\
\hline
\end{tabular}


To be able to observe if the decrease of the efficiency of the gears is due to the optimum arrangement of the gears or the fact that the value of the angle of pressure alpha 0 has changed by increasing, then the recalculation of the new stages optimized with the same values for the angles of pressure and inclination of the gear will proceed as in the case used initially and it will be observed that the gears' returns go back to the initial values, so their decrease was mainly due not to the fact that the tooth numbers of the wheels were optimized in order to obtain optimum transmission ratios but due to the fact that the value of the pressure angle had been raised to close to the known standard value of 20 [deg]:

1) $\eta_{0}$ is determined for gear 1.2 directly with relations I and I:

$$
\begin{gathered}
\eta_{0} \\
0,85392
\end{gathered}
$$

2) $\eta_{78}$ is determined for gear 7.8 with relations I and II, where 1 is replaced by 7 and 2 is replaced by 8 . The yield in step 3 is then obtained through the product between the yield 0 and that of gear $7.8 ; \eta_{3}=\eta_{0} \cdot \eta_{78}$ :

$$
\begin{gathered}
\eta_{78} \\
0,82739 \\
\eta_{3} \\
0,70653
\end{gathered}
$$

3) $\eta_{9,10}$ is determined for the gear 9.10 with relations I and II, where 1 is replaced by 9 and 2 is replaced by 10. The yield in step 4 is then obtained by the product between the yield 0 and that of the gear $9.10 ; \eta_{4}=\eta_{0} \cdot \eta_{9,10}$ :

$$
\begin{gathered}
\eta_{9,10} \\
0,83729 \\
\eta_{4} \\
0,71498
\end{gathered}
$$

4) $\eta_{11,12}$ is determined for the gear 11.12 with relations I and II, where 1 is replaced by 11 and 2 is replaced by 12 . The yield in step 5 is then obtained by the product between the yield 0 and that of the gear $11.12 ; \eta_{5}=\eta_{0} \cdot \eta_{11,12}$ :

$$
\begin{gathered}
\eta_{11,12} \\
0,85344 \\
\eta_{5} \\
0,72877
\end{gathered}
$$

The angles $\alpha_{0}, \beta$ are constant for all the gears of this gearbox as follows: $\alpha_{0}=18.6, \beta=16$.
We will continue to repeat the final experiment, with optimized transmission ratios, but using a much lower pressure angle, in an attempt to achieve higher efficiencies at the main gear gears:

1) $\eta_{0}$ is determined for gear 1.2 directly with relations I and II:

$$
\begin{gathered}
\eta_{0} \\
0,93314
\end{gathered}
$$

2) $\eta_{78}$ is determined for gear 7.8 with relations I and II, where 1 is replaced by 7 and 2 is replaced by 8 . The yield in step 3 is then obtained through the product between the yield 0 and that of gear $7.8 ; \eta_{3}=\eta_{0} \cdot \eta_{78}$ :

$$
\begin{gathered}
\eta_{78} \\
0,89096 \\
\eta_{3} \\
0,83139
\end{gathered}
$$

3) $\eta_{9,10}$ is determined for the gear 9.10 with relations I and II, where 1 is replaced by 9 and 2 is replaced by 10. The yield in step 4 is then obtained by the product between the yield 0 and that of the gear 9.10; $\eta_{4}=\eta_{0} \cdot \eta_{9,10}$ :

$$
\begin{gathered}
\eta_{9,10} \\
0,90950 \\
\eta_{4} \\
0,84869
\end{gathered}
$$

4) $\eta_{11,12}$ is determined for the gear 11.12 with relations I and II, where 1 is replaced by 11 and 2 is replaced by 12 . The yield in step 5 is then obtained by the product between the yield 0 and that of the gear $11.12 ; \eta_{5}=\eta_{0} \cdot \eta_{11,12}$ :

$$
\begin{gathered}
\eta_{11,12} \\
0,93716 \\
\eta_{5} \\
0,87450
\end{gathered}
$$

The angles $\alpha_{0}, \beta$ are constant for all the gears of this gearbox as follows: $\alpha_{0}=4, \beta=40$.

It is observed the increase of the efficiency in all the gears due to the decrease of the angle of pressure to gears to the value 4 [deg], in the conditions in which the numbers of optimized teeth were used to have some ratios of optimal transmission and power in all the gears speeds.

In fact, this is the main innovation brought about by the paper and by the original relations of calculation of the yield (I and II) used in the paper.

From a technological point of view, it is not too easy to lower the alpha angle of pressure to such a low value, 4 
[deg]. Initially following the new theory proposed by the authors of this paper, since 2002, in France, the gear pressure angle has been reduced by only 4 [deg] from 20 [deg] to 16 [deg], but in the United States a little later, in laboratories of aerospace including NASA managed to reach values of 10-12 [deg], but did not go below 10 [deg], in the years 2010-2014. The authors of the paper verified various possible scenarios with the INVENTOR software, in 2014 (Petrescu and Petrescu, 2014a) and all the values obtained with the help of the new calculation relationships, I and II, were fully verified with those obtained with the help of the Inventor 2014 software, from alpha $0=10[\mathrm{deg}]$ the alpha $0=30$ [deg]. Undervalue 10 [deg] the software said that it has no experimental data and cannot calculate the values proposed by the authors, on that date 2014 . Even so with only alpha0 $=10$ [deg] the values of the gears can be greatly optimized if the number is increased the teeth of the wheels used in gears, with the possible increase of the gauge, but with the great advantage of obtaining very high efficiency in the mechanical transmissions with fixed gears used.

\section{Conclusion}

Fixed axis mechanical transmissions today have the largest spread on the entire planet, being practically used in almost all areas. From the gearboxes of the vehicles to the stationary reducers, used in the electrical, electronic and electrotechnical equipment, in the heavy industry but also in the light industry, in energy and in transport, practically the transmissions with fixed axes meet today everywhere, being part of our daily life. For this reason, we want to present the kinematic and dynamic analysis at a classic, manual, three-axis gearbox, with six speeds, without a direct socket. With the help of the presented method, one can analyze the dynamics of such a gearbox in order to design it optimally, so as to achieve the highest yields in operation, especially in the most used speeds, so that the transmission losses are limited to up.

The classic gearboxes, manual, the most widespread and most used, are mainly of three types: With two axes (Fig. 8), with three axes with welding the input and output shafts in the direct socket (Fig. 9), with three axles without welding shafts (Fig. 10).

The paper examines how the geometrical-kinematic and dynamic analysis based on its yield and is performed based on a classic, manual, three-axis gearbox, without a direct socket, a model that is widely used in the automotive industry worldwide, from the beginnings of the car and until today, even if in the meantime there have been automatic gearboxes, or other with two gearboxes classics, to which a double-clutch has been added.

The efficiency results in the main gears, which are used more often by the driver of the vehicle, are generally high and could be optimized so that they are even higher with the optimum design of the gearbox, with gears having a larger number of teeth and possibly with decreasing the pressure angle normal on the division circle to an optimum value.

\section{Acknowledgement}

This text was acknowledged and appreciated by Dr. Veturia CHIROIU Honorific member of Technical Sciences Academy of Romania (ASTR) Ph.D. supervisor in Mechanical Engineering.

\section{Funding Information}

Research contract: Contract number 36-5-4D/1986 from 24IV1985, beneficiary CNST RO (Romanian National Center for Science and Technology) Improving dynamic mechanisms internal combustion engines.

\section{!All These Matters are Copyrighted!}

Copyrights:

1. New Aircraft (New Ionic or Beam Engines): no. 548 of 22-04-2010 [cgiywDssin], Aerospace Engineering

2. Some Few Specifications About the Doppler Effect to the Electromagnetic Waves: 636 of 28-05-2010 [iEtcaouxxA], physics

3. Presenting an Atomic Model and Some Possible Applications in LASER Field: Nr. 639 of 29-052010 [yncngrotfo], physics

4. Some Applications in LASER Field: No. 718 of 0907-2010 [xeujouincC], physics

5. The Energies of Today and Tomorrow: Nr. 819 of 30-09-2010 [kbHquxwykr], energy engineering

6. Obtaining Energy by the Annihilation of the Matter with Antimatter - The Battle for Energy: Nr. 1068 of 13.03.2011 [GfEqpGDzeh], Energy Engineering

\section{Author's Contributions}

All the authors contributed equally to prepare, develop and carry out this manuscript.

\section{Ethics}

This article is original and contains unpublished material. Authors declare that are not ethical issues and no conflict of interest that may arise after the publication of this manuscript.

\section{References}

Antonescu, P. and F.I.T. Petrescu, 1985. An analytical method of synthesis of cam mechanism and flat stick. Proceedings of the 4th International Symposium on Theory and Practice of Mechanisms, (TPM' 89), Bucharest. 
Antonescu, P. and F.I.T. Petrescu, 1989. Contributions to kinetoplast dynamic analysis of distribution mechanisms.

Antonescu, P., F.I.T. Petrescu and D. Antonescu, 1997. Geometrical synthesis of the rotary cam and balance tappet mechanism. Bucharest, 3: 23-23.

Antonescu, P., F.I.T. Petrescu and O. Antonescu, 1994. Contributions to the synthesis of the rotating cam mechanism and the tip of the balancing tip. Brasov.

Antonescu, P., F.I.T. Petrescu and O. Antonescu, 2000a. Contributions to the synthesis of the rotary disc-cam profile. Proceedings of the 8th International Conference on the Theory of Machines and Mechanisms, (TMM' 00), Liberec, Czech Republic, pp: 51-56.

Antonescu, P., F.I.T. Petrescu and O. Antonescu, 2000b. Synthesis of the rotary cam profile with balance follower. Proceedings of the 8th Symposium on Mechanisms and Mechanical Transmissions, (MMT' 00), Timişoara, pp: 39-44.

Antonescu, P., F.I.T. Petrescu and O. Antonescu, 2001. Contributions to the synthesis of mechanisms with rotary disc-cam. Proceedings of the 8th IFToMM International Symposium on Theory of Machines and Mechanisms, (TMM' 01), Bucharest, Romania, pp: 31-36.

Antonescu, P., M. Oprean and F. Petrescu, 1988. Analytical synthesis of Kurz profile, rotating the flat cam. Mach. Build. Rev.

Antonescu, P., M. Oprean and F.I.T. Petrescu, 1985a. Contributions to the synthesis of oscillating cam mechanism and oscillating flat stick. Proceedings of the 4th International Symposium on Theory and Practice of Mechanisms, (TPM' 85), Bucharest.

Antonescu, P., M. Oprean and F.I.T. Petrescu, 1985b. At the projection of the oscillate cams, there are mechanisms and distribution variables. Proceedings of the 5th Conference of Engines, Automobiles, Tractors and Agricultural Machines, (TAM' 58), IMotors and Cars, Brasov.

Antonescu, P., M. Oprean and F.I.T. Petrescu, 1986. Projection of the profile of the rotating camshaft acting on the oscillating plate with disengagement. Proceedings of the 3rd National Computer-aided Design Symposium in the field of Mechanisms and Machine Parts, (MMP' 86), Brasov.

Antonescu, P., M. Oprean and F.I.T. Petrescu, 1987. Dynamic analysis of the cam distribution mechanisms. Proceedings of the 7th National Symposium on Industrial Robots and Space Mechanisms, (RSM' 87), Bucharest.

Aversa, R., F.I.T. Petrescu, R.V. Petrescu and A. Apicella, 2016a. Biomimetic FEA bone modeling for customized hybrid biological prostheses development. Am. J. Applied Sci., 13: 1060-1067. DOI: 10.3844 /ajassp.2016.1060.1067
Aversa, R., D. Parcesepe, R.V. Petrescu, G. Chen and F.I.T. Petrescu et al., 2016b. Glassy amorphous metal injection molded induced morphological defects. Am. J. Applied Sci., 13: 1476-1482. DOI: 10.3844/ajassp.2016.1476.1482

Aversa, R., R.V. Petrescu, F.I.T. Petrescu and A. Apicella, 2016c. Smart-factory: Optimization and process control of composite centrifuged pipes. Am. J. Applied Sci., 13: 1330-1341. DOI: 10.3844/ajassp.2016.1330.1341

Aversa, R., F. Tamburrino, R.V. Petrescu, F.I.T. Petrescu and M. Artur et al., 2016d. Biomechanically inspired shape memory effect machines driven by muscle like acting NiTi alloys. Am. J. Applied Sci., 13: 1264-1271. DOI: 10.3844/ajassp.2016.1264.1271

Aversa, R., R.V.V. Petrescu, A. Apicella and F.I.T. Petrescu, 2017a. Nano-diamond hybrid materials for structural biomedical application. Am. J. Biochem. Biotechnol., 13: 34-41. DOI: 10.3844/ajbbsp.2017.34.41

Aversa, R., R.V. Petrescu, B. Akash, R.B. Bucinell and J.M. Corchado et al., 2017b. Kinematics and forces to a new model forging manipulator. Am. J. Applied Sci., 14: 60-80. DOI: 10.3844/ajassp.2017.60.80

Aversa, R., R.V. Petrescu, A. Apicella, F.I.T. Petrescu and J.K. Calautit et al., 2017c. Something about the $\mathrm{V}$ engines design. Am. J. Applied Sci., 14: 34-52. DOI: 10.3844/ajassp.2017.34.52

Aversa, R., D. Parcesepe, R.V.V. Petrescu, F. Berto and G. Chen et al., 2017d. Process ability of bulk metallic glasses. Am. J. Applied Sci., 14: 294-301. DOI: 10.3844/ajassp.2017.294.301

Aversa, R., R.V. Petrescu, A. Apicella, S. Kozaitis and T. Abu-Lebdeh et al., 2017e. Triton for nuclear fusion. Am. J. Eng. Applied Sci., 10: 992-1000. DOI: 10.3844/ajeassp.2017.992.1000

Brewer, G.D., 1991. Hydrogen Aircraft Technology, CRC Press, Boca Raton.

Cao, W., H. Ding, Z. Bin and C. Ziming, 2013. New structural representation and digital-analysis platform for symmetrical parallel mechanisms. Int. J. Adv. Robotic Sys.

Dong, H., N. Giakoumidis, N. Figueroa and N. Mavridis, 2013. Approaching behaviour monitor and vibration indication in developing a General Moving Object Alarm System (GMOAS). Int. J. Adv. Robotic Sys.

Franklin, D.J., 1930. Ingenious Mechanisms for Designers and Inventors. 1st Edn., Industrial Press Inc., ISBN-10: 0831110325, pp: 486.

He, B., Z. Wang, Q. Li, H. Xie and R. Shen, 2013. An analytic method for the kinematics and dynamics of a multiple-backbone continuum robot. Int. J. Adv. Robotic Sys. 
Lee, B.J., 2013. Geometrical derivation of differential kinematics to calibrate model parameters of flexible manipulator. Int. J. Adv. Robotic Sys.

Lin, W., B. Li, X. Yang and D. Zhang, 2013. Modelling and control of inverse dynamics for a 5-DOF parallel kinematic polishing machine. Int. J. Adv. Robotic Sys.

Liu, H., W. Zhou, X. Lai and S. Zhu, 2013. An efficient inverse kinematic algorithm for a PUMA560structured robot manipulator. Int. J. Adv. Robotic Sys.

Padula, F. and V. Perdereau, 2013. An on-line path planner for industrial manipulators. Int. J. Adv. Robotic Sys.

Perumaal, S. and N. Jawahar, 2013. Automated trajectory planner of industrial robot for pick-andplace task. Int. J. Adv. Robotic Sys.

Petrescu, F.I.T. and R. Petrescu, 2011a. Mechanical Systems, Serial and Parallel (Romanian). 1st Edn., LULU Publisher, London, UK, ISBN-10: 1446600394, pp: 124.

Petrescu, F.I.T. and R. Petrescu, 2011b. Trenuri Planetare. 1st Edn., Createspace Independent, ISBN-13: 978-1468030419. pp: 104.

Petrescu F.I.T and R.V. Petrescu, 2011c. Determination of the mechanical efficiency of the gears, Ingineria Automobilului.

Petrescu, F.I.T. and R. Petrescu, 2013a. Cinematics of the 3R dyad. Engevista, 15: 118-124. DOI: 10.22409/engevista.v15i2.376

Petrescu, F.I. and R.V. Petrescu, 2013b. Cams with high efficiency, international review of mechanical engineering I.RE.M.E. J., 7: 599-606.

Petrescu, F.I. and R.V. Petrescu, 2013c. An algorithm for setting the dynamic parameters of the classic distribution mechanism. Int. Rev. Modell. Simulations, 6: 1637-1641.

Petrescu, F.I. and R.V. Petrescu, 2013d. Dynamic synthesis of the rotary cam and translated tappet with roll. Int. Rev. Modell. Simulations J., 6: 600-607.

Petrescu, F.I. and R.V. Petrescu, 2013e. Forces and efficiency of cams. Int. Rev. Mech. Eng. J., 7: 507-511.

Petrescu, F.I.T. and R.V. Petrescu, 2014a. High-efficiency gears, Facta Univ. Series Mech. Eng., 12: 51-60.

Petrescu, F.I.T. and R.V. Petrescu, 2014b. Cam gears dynamics in the classic distribution. Independent J. Manage. Produc., 5: 166-185. DOI: 10.14807/ijmp.v5i1.133

Petrescu, F.I.T. and R.V. Petrescu, 2014c. Highefficiency gears synthesis by avoid the interferences. Independent J. Manage. Produc., 5: 275-298. DOI: $10.14807 /$ ijmp.v5i2.147

Petrescu, F.I. and R.V. Petrescu, 2014d. Balancing OTTO Engines. Int. Rev. Mech. Eng. J., 8: 473-480.

Petrescu, F.I. and R.V. Petrescu, 2014e. Machine equations to the classical distribution. Int. Rev. Mech. Eng. J., 8: 309-316.
Petrescu, F.I. and R.V. Petrescu, 2014f. Forces of internal combustion heat engines. Int. Rev. Modell. Simulations J., 7: 206-212.

Petrescu, F.I. and R.V. Petrescu, 2014g. Determination of the yield of internal combustion thermal engines. Int. Rev. Mech. Eng. J., 8: 62-67.

Petrescu, F.I. and R.V. Petrescu, 2014h. Cam dynamic synthesis. Al-Khwarizmi Eng. J. Baghdad Univ., 10: 1-23.

Petrescu, F.I.T. and K.J. Calautit, 2016a. About nano fusion and dynamic fusion. Am. J. Applied Sci., 13: 261-266. DOI: 10.3844/ajassp.2016.261.266

Petrescu, F.I.T. and K.J. Calautit, 2016b. About the light dimensions. Am. J. Applied Sci., 13: 321-325. DOI: 10.3844/ajassp.2016.321.325

Petrescu, F.I.T. and R. Petrescu, 1995a. Contributions to optimization of the polynomial motion laws of the stick from the internal combustion engine distribution mechanism. Bucharest, 1: 249-256.

Petrescu, F.I.T. and R. Petrescu, 1995b. Contributions to the synthesis of internal combustion engine distribution mechanisms. Bucharest, 1: 257-264.

Petrescu, F.I.T. and R. Petrescu, 1997a. Dynamics of cam mechanisms (exemplified on the classic distribution mechanism). Bucharest, 3: 353-358.

Petrescu, F.I.T. and R. Petrescu, 1997b. Contributions to the synthesis of the distribution mechanisms of internal combustion engines with a Cartesian coordinate method. Bucharest, 3: 359-364.

Petrescu, F.I.T. and R. Petrescu, 1997c. Contributions to maximizing polynomial laws for the active stroke of the distribution mechanism from internal combustion engines. Bucharest, 3: 365-370.

Petrescu, F.I.T. and R. Petrescu, 2000a. Synthesis of distribution mechanisms by the rectangular (Cartesian) coordinate method. Proceedings of the 8th National Conference on International Participation, (CIP' 00), Craiova, Romania, pp: 297-302.

Petrescu, F.I.T. and R. Petrescu, 2000b. The design (synthesis) of cams using the polar coordinate method (triangle method). Proceedings of the 8th National Conference on International Participation, (CIP’ 00), Craiova, Romania, pp: 291-296.

Petrescu, F.I.T. and R. Petrescu, 2002a. Motion laws for cams. Proceedings of the International Computer Assisted Design, National Symposium Participation, (SNP' 02), Braşov, pp: 321-326.

Petrescu, F.I.T. and R. Petrescu, 2002b. Camshaft dynamics elements. Proceedings of the International Computer Assisted Design, National Participation Symposium, (SNP' 02), Braşov, pp: 327-332.

Petrescu, F.I.T. and R. Petrescu, 2003. Some elements regarding the improvement of the engine design. Proceedings of the National Symposium, Descriptive Geometry, Technical Graphics and Design, (GTD’03), Braşov, pp: 353-358. 
Petrescu, F.I.T. and R. Petrescu, 2005a. The cam design for a better efficiency. Proceedings of the International Conference on Engineering Graphics and Design, (EGD’05), Bucharest, pp: 245-248.

Petrescu, F.I.T. and R. Petrescu, 2005b. Contributions at the dynamics of cams. Proceedings of the 9th IFToMM International Symposium on Theory of Machines and Mechanisms, (TMM' 05), Bucharest, Romania, pp: 123-128.

Petrescu, F.I.T. and R. Petrescu, 2005c. Determining the dynamic efficiency of cams. Proceedings of the 9th IFToMM International Symposium on Theory of Machines and Mechanisms, (TMM' 05), Bucharest, Romania, pp: 129-134.

Petrescu, F.I.T. and R. Petrescu, 2005d. An original internal combustion engine. Proceedings of the 9th IFToMM International Symposium on Theory of Machines and Mechanisms, (TMM' 05), Bucharest, Romania, pp: 135-140.

Petrescu, F.I.T. and R. Petrescu, 2005e. Determining the mechanical efficiency of Otto engine's mechanism. Proceedings of the 9th IFToMM International Symposium on Theory of Machines and Mechanisms, (TMM' 05), Bucharest, Romania, pp: 141-146.

Petrescu, F.I.T. and R. Petrescu, 2012a. Kinematics of the planar quadrilateral mechanism. Engevista, 14: 345-348. DOI: 10.22409/engevista.v14i3.377

Petrescu, F.I.T. and R. Petrescu, 2012b. MecatronicaSisteme Seriale si Paralele. 1st Edn., Create Space Publisher, USA, pp: 128.

Petrescu, F.I.T. and R. Petrescu, 2016a. Parallel moving mechanical systems kinematics. Engevista, 18: 455-491. DOI: 10.22409/engevista.v18i2.733

Petrescu, F.I.T. and R. Petrescu, 2016b. Direct and inverse kinematics to the anthropomorphic robots. Engevista, 18: 109-124. DOI: 10.22409/engevista.v18i1.729

Petrescu, F.I.T. and R. Petrescu, 2016c. Dynamic cinematic to a structure 2R. Revista Geintec-Gestao Inovacao E Tecnol., 6: 3143-3154. DOI: $10.7198 / \mathrm{S} 2237-0722201600020012$

Petrescu, F.I.T. and R.V.V. Petrescu, 2019a. An algorithm to determining the gear efficiency to a simple planetary train. Independent J. Manage. Produc., 10: 1392-1404. DOI: 10.14807/ijmp.v10i5.392

Petrescu, R.V.V. and F.I.T. Petrescu, 2019b. Structuraltopological synthesis of space mechanisms with rods and wheels. Independent J. Manage. Produc., 10: 1446-1475. DOI: 10.14807/ijmp.v10i5.902

Petrescu, F.I.T. and R.V.V. Petrescu, 2019c. Application to rigid memory mechanisms of a variable internal dynamic damping model. Independent J. Manage. Produc., 10: 1994-2022.

DOI: $10.14807 /$ ijmp.v10i6.905
Petrescu, F.I.T., 2011. Teoria Mecanismelor si a Masinilor: Curs Si Aplicatii. 1st Edn., Create Space Independent Publishing Platform, ISBN-10: 1468015826, pp: 432.

Petrescu, F.I.T., 2012. Cold nuclear fusion. Plasma Phys. Fusion Technol., 44: 100-100.

Petrescu, F.I.T., 2019. About the nuclear particles' structure and dimensions. Comp. Part. Mech., 6: 191-194. DOI: 10.1007/S40571-018-0206-7

Petrescu, F.I.T., A. Apicella, R.V. Petrescu, S.P. Kozaitis and R.B. Bucinell et al., 2016. Environmental protection through nuclear energy. Am. J. Applied Sci., 13: 941-946. DOI: 10.3844/ajassp.2016.941.946

Petrescu, F.I.T., B. Grecu, A. Comanescu and R.V. Petrescu, 2009. Some mechanical design elements. Proceeding of the International Conference on Computational Mechanics and Virtual Engineering, (MVE' 09), Braşov, pp: 520-525.

Petrescu, R.V., R. Aversa, B. Akash, R. Bucinell and J. Corchado et al., 2017a. Modern propulsions for aerospace-a review. J. Aircraft Spacecraft Technol., 1: 1-8. DOI: 10.3844/jastsp.2017.1.8

Petrescu, R.V., R. Aversa, B. Akash, R. Bucinell and J. Corchado et al., 2017b. Modern propulsions for aerospace-part II. J. Aircraft Spacecraft Technol., 1: 9-17. DOI: 10.3844/jastsp.2017.9.17

Petrescu, R.V., R. Aversa, B. Akash, R. Bucinell and J. Corchado et al., 2017c. History of aviation-a short review. J. Aircraft Spacecraft Technol., 1: 30-49. DOI: 10.3844/jastsp.2017.30.49

Petrescu, R.V., R. Aversa, B. Akash, R. Bucinell and J. Corchado et al., 2017d. Lockheed martin-a short review. J. Aircraft Spacecraft Technol., 1: 50-68. DOI: 10.3844 /jastsp.2017.50.68

Petrescu, R.V., R. Aversa, B. Akash, J. Corchado et al., 2017e. Our universe. J. Aircraft Spacecraft Technol., 1: 69-79. DOI: 10.3844/jastsp.2017.69.79

Petrescu, R.V., R. Aversa, B. Akash, R. Bucinell and J. Corchado et al., 2017f. What is a UFO? J. Aircraft Spacecraft Technol., 1: 80-90. DOI: 10.3844 jastsp.2017.80.90

Petrescu, R.V., R. Aversa, B. Akash, R. Bucinell and J. Corchado et al., 2017g. About bell helicopter FCX001 concept aircraft-a short review. J. Aircraft Spacecraft Technol., 1: 91-96. DOI: 10.3844 /jastsp.2017.91.96

Petrescu, R.V., R. Aversa, B. Akash, R. Bucinell and J. Corchado et al., 2017h. Home at airbus. J. Aircraft Spacecraft Technol., 1: 97-118. DOI: $10.3844 /$ jastsp.2017.97.118

Petrescu, R.V., R. Aversa, B. Akash, R. Bucinell and J. Corchado et al., 2017i. Airlander. J. Aircraft Spacecraft Technol., 1: 119-148. DOI: $10.3844 /$ jastsp.2017.119.148 
Petrescu, R.V., R. Aversa, B. Akash, R. Bucinell and J. Corchado et al., 2017j. When boeing is dreaming-a review. J. Aircraft Spacecraft Technol., 1: 149-161. DOI: $10.3844 /$ jastsp.2017.149.161

Petrescu, R.V., R. Aversa, B. Akash, R. Bucinell and J. Corchado et al., 2017k. About Northrop Grumman. J. Aircraft Spacecraft Technol., 1: 162-185. DOI: $10.3844 /$ jastsp.2017.162.185

Petrescu, R.V., R. Aversa, B. Akash, R. Bucinell and J. Corchado et al., 20171. Some special aircraft. J. Aircraft Spacecraft Technol., 1: 186-203. DOI: $10.3844 /$ jastsp.2017.186.203

Petrescu, R.V., R. Aversa, B. Akash, R. Bucinell and J. Corchado et al., 2017m. About helicopters. J. Aircraft Spacecraft Technol., 1: 204-223. DOI: 10.3844/jastsp.2017.204.223

Petrescu, R.V., R. Aversa, B. Akash, F. Berto and A. Apicella et al., 2017n. The modern flight. J. Aircraft Spacecraft Technol., 1: 224-233. DOI: 10.3844 /jastsp.2017.224.233

Petrescu, R.V., R. Aversa, B. Akash, F. Berto and A. Apicella et al., 2017o. Sustainable energy for aerospace vessels. J. Aircraft Spacecraft Technol., 1: 234-240. DOI: 10.3844/jastsp.2017.234.240

Petrescu, R.V., R. Aversa, B. Akash, F. Berto and A. Apicella et al., 2017p. Unmanned helicopters. J. Aircraft Spacecraft Technol., 1: 241-248.

DOI: $10.3844 /$ jastsp.2017.241.248

Petrescu, R.V., R. Aversa, B. Akash, F. Berto and A. Apicella et al., 2017q. Project HARP. J. Aircraft Spacecraft Technol., 1: 249-257. DOI: $10.3844 /$ jastsp.2017.249.257

Petrescu, R.V., R. Aversa, B. Akash, F. Berto and A. Apicella et al., 2017r. Presentation of Romanian engineers who contributed to the development of global aeronautics-part I. J. Aircraft Spacecraft Technol., 1: 258-271. DOI: $10.3844 /$ jastsp.2017.258.271

Petrescu, R.V., R. Aversa, B. Akash, F. Berto and A. Apicella et al., 2017s. A first-class ticket to the planet mars, please. J. Aircraft Spacecraft Technol., 1: 272-281. DOI: 10.3844/jastsp.2017.272.281

Petrescu, R.V., R. Aversa, S. Li, R. Bucinell and S. Kozaitis et al., 2017t. Electron dimensions. Am. J. Eng. Applied Sci., 10: 584-602. DOI: 10.3844/ajeassp.2017.584.602

Petrescu, R.V., R. Aversa, S. Kozaitis, A. Apicella and F.I.T. Petrescu, 2017u. Deuteron dimensions. Am. J. Eng. Applied Sci., 10: 649-654. DOI: 10.3844/ajeassp.2017.649.654

Petrescu, R.V., R. Aversa, S. Kozaitis, A. Apicella and F.I.T. Petrescu, 2017v. Some proposed solutions to achieve nuclear fusion. Am. J. Eng. Applied Sci., 10: 703-708. DOI: 10.3844/ajeassp.2017.703.708
Petrescu, R.V., R. Aversa, S. Kozaitis, A. Apicella and F.I.T. Petrescu, 2017w. Some basic reactions in nuclear fusion. Am. J. Eng. Applied Sci., 10: 709-716. DOI: 10.3844/ajeassp.2017.709.716

Petrescu, F.I.T., R.V. Petrescu and M. Mirsayar, 2017x. The computer algorithm for machine equations of classical distribution. J. Mater. Eng. Structures, 4: 193-209.

Petrescu, R.V., R. Aversa, A. Apicella and F.I.T. Petrescu, 2018a. Romanian engineering "on the wings of the wind". J. Aircraft Spacecraft Technol., 2: 1-18. DOI: 10.3844/jastsp.2018.1.18

Petrescu, R.V., R. Aversa, A. Apicella and F.I.T. Petrescu, 2018b. NASA Data used to discover eighth planet circling distant star. J. Aircraft Spacecraft Technol., 2: 19-30. DOI: 10.3844/jastsp.2018.19.30

Petrescu, R.V., R. Aversa, A. Apicella and F.I.T. Petrescu, 2018c. NASA has found the most distant black hole. J. Aircraft Spacecraft Technol., 2: 31-39. DOI: 10.3844 /jastsp.2018.31.39

Petrescu, R.V., R. Aversa, A. Apicella and F.I.T. Petrescu, 2018d. Nasa selects concepts for a new mission to titan, the moon of saturn. J. Aircraft Spacecraft Technol., 2: 40-52. DOI: 10.3844/jastsp.2018.40.52

Petrescu, R.V., R. Aversa, A. Apicella and F.I.T. Petrescu, 2018e. NASA sees first in 2018 the direct proof of ozone hole recovery. J. Aircraft Spacecraft Technol., 2: 53-64. DOI: 10.3844/jastsp.2018.53.64

Petrescu, R.V., R. Aversa, A. Apicella and F.I.T. Petrescu, 2018f. Modern propulsions for the aerospace industry. Am. J. Eng. Applied Sci., 11: 715-755. DOI: 10.3844/ajeassp.2018.715.755

Petrescu, F.I.T., R.V. Petrescu and M. Mirsayar, 2018g. Inverse kinematics to a Stewart platform. J. Mater. Eng. Structures, 5: 111-122.

Petrescu, R.V., F.I.T. Petrescu and N. Popescu, 2007. Determining gear efficiency. Gear Solutions, 5: 20-28.

Svensson, F., A. Hasselrot and J. Moldanova, 2004. Reduced environmental impact by lowered cruise altitude for liquid hydrogen-fuelled aircraft, Aerospace Sci. Technol. Elsevier Sci., 8: 307-320. DOI: $10.1016 /$ j.ast.2004.02.004

\section{Source of Figures:}

Figure 01-09:

Petrescu and Petrescu, 2011b, 2014; Petrescu, 2011

Figure 10:

Made by authors. 